原著

大腸ファイバースコープ (CF)・注腸 X 線検査同日併用法の検討

\begin{tabular}{|c|c|c|c|c|c|c|c|c|c|c|}
\hline \multirow[b]{2}{*}{ 大 } & \multicolumn{4}{|c|}{ 群馬大学第 2 外科 } & \multicolumn{2}{|c|}{ （主任：泉雄 } & \multicolumn{4}{|c|}{ 勝教授) } \\
\hline & 和 & 田 & 進 & 竹 & 吉 & 泉 & 水 & 口 & 洨 & 之 \\
\hline 中 & 村 & 正 & 治 & 岩 & 崎 & 茂 & 宮 & 本 & 幸 & 男 \\
\hline & 雄 & & 勝 & & & & & & & \\
\hline
\end{tabular}

横森忠紘谷口棟一郎家里裕

外科外来において大腸癌を早期発見するため，大腸ファイバースコーブ(CF)・注腸 X 線同日併用検查扰よび $\mathrm{CF}$ 先行検查を215例に施行しその有用性について検討した. 癌21 例、ポリーブ41例57病変が診断された。この併用検查の利点として, 1. 前処置が 1 回で 被検者の負担が軽隇される。. 2. 有愁訴者に CF 愉査を先行することで早期診断, 早期治 療が可能となり，場合によっては同日注腸検査を省略できる.3，病变の好発する左側結 腸, 特に S 状結腸, 直腸の double check ができ, 大腸癌の早期発見の手段としては奻率 がよい，久点として，CF を先行することで air lock，粘液分泌等により注腸二重造影所 見が多少不良となりX線診断能の低下が考えられた。

臬引用語：大腸矢患訩断法，大腸フォイバー検査法，注腸 X 線検査法

\section{緒 讋}

近年, 大腸癌の罹患率は本邦でる急增しており，そ の治㢈率の向上には早期発見が肝要である，早期発見 の方法として, 無愁訴集団人の便潜血反応等の工夫, 進歩”がみられる.しかし，検診陽性例，有愁訴集団へ のスクリーニング法には，いまた確立された方法はな い.

今回，下部消化管有愁訴者に対しロマノスコープ， 注腸 X 線同日併用検査を施行してきた経験より，ロマ ノスコープを中間長ファイハースコープに变えて Colonofiberscopy (CF) 注腸 X 線同日併用検查を施行 したのでその成綪について報告する。

\section{対争と方法}

研究対象は関連病院である新渴県小千谷総合病院 に, 昭和58年 1 月から昭和59年 5 月迄の16力月間に, 何等かの下部消化管の愁訴をるって外来を訪九た患者 を对象とした，その内訳は CF 注腸 X 線同日併用111 例, CF 単独104例の計215例であった前処直は Brown 変法で行い,ボンコロン 3 食, マグコロール250ml, ブ ルセニド2T,レシカルポン坐薬 2 個を使用した.CFは

昭和 62 年 5 月 22 日受付 62 年11月16日採用
主にCFMB3R or CFLB3を用いて無透視下，医師 1 名，看護婦 1 名で行った。注腸 X 線検查は CF 後, 約 1 時間後に65\%ハシウムを用いて二重造影法を行。 た。何れの検査も午前中に実施した。

\section{成縝}

\section{1. 対象の分析}

主訴は表 1 に示したごとく205症例中，下血65例， $31.7 \%$ ，血便35例， $17.1 \%$ と，出血徵候は約 $50 \%$ を占 めた。 その他，肛門痛，腹痛，下㢉，排便異常など， 肛門咨患と紛らわしいものを含めると $75 \%$ に厓した。 対象患者の年龄分布は40代から70代がそれぞれ約 $20 \%$ と均等に分布していた(表 2). 男女比ははぼ：1で あった。

\section{CF の到達観察筙囲}

$\mathrm{S}$ 状，下行結腸移行部まで $41.5 \%$ ，下行結腸 $28.3 \%$, 脾結腸曲 $21.4 \%$ ，横行結腸より口側は8.8\%であった。 約 $60 \%$ で左側結腸のスクリーニングが可能であった (静 3 ).

\section{3. 前処置，注得二重造影の評価}

CF の前処置不良は17例，15\%で 6 例，5.4\%は浣渴 を必要とした。注腸 X 線検查では, 粘膜描出不良19例， $17.1 \%$ ，造影不良15例，13.5\%であった，これらを検 
表 1 主䄠

\begin{tabular}{|c|c|c|}
\hline 主 訴 & 店例数 $(n=205)$ & 頻度 $(\%)$ \\
\hline 下 & 65 & 31.7 \\
\hline 血 & 35 & 17.1 \\
\hline 肛 門 痡 & 19 & 9.3 \\
\hline 腹 & 19 & 9.3 \\
\hline 便 & 15 & 7.3 \\
\hline テネスムス & 4 & 1.9 \\
\hline 下 & 4 & 1.9 \\
\hline 便柱筷小 & 4 & 1.9 \\
\hline 交 代 便 & 3 & 1.5 \\
\hline 䨘 & 2 & 1.0 \\
\hline その 他 & 35 & 17.1 \\
\hline
\end{tabular}

表 2 年龄分布

\begin{tabular}{c|c|c}
\hline \multicolumn{1}{c|}{ 年㗼 } & 症例数 $(\mathrm{n}=205)$ & 頻度 $(\%)$ \\
\hline$\leqq 29$ & 6 & 2.9 \\
$30 \sim 39$ & 28 & 13.6 \\
$40 \sim 49$ & 44 & 21.5 \\
$50 \sim 59$ & 44 & 21.5 \\
$60 \sim 69$ & 36 & 17.6 \\
$70 \sim 79$ & 44 & 21.5 \\
$80 \leqq$ & 3 & 1.4 \\
\hline
\end{tabular}

表 3 CF 锶察簤囲

\begin{tabular}{l|c|c}
\hline & 症例数 $(\mathrm{n}=205)$ & 頻度 $(\%)$ \\
\hline S 状・下行結腸移行部 & 85 & 41.5 \\
下行結腸 & 58 & 28.3 \\
脾結晹曲 & 44 & 21.4 \\
横行結腸以上 & 18 & 8.8 \\
\hline
\end{tabular}

查医の経験年数に上って前期（卒後 4 年生）と後期（卒 後 3 年生）に分けて検討すると，後期に覀い㑯向があ ク，検查手技の習熟度の差と考えられた（表 4)。

\section{CF，注腸 X 線同日検査の診断病空}

111 症例中に癌 6 例，ボリーブ25例，34病変が拾い上 げられ，隆起性病変の診断は約28\%であった。大腸炎 は6 例診断された（表 5 ）。

\section{CF と注腸 X 線同日検査の不一致}

$\mathrm{CF}$ 到達範囲は CF を正診とし，CF 非到達範囲は注 腸を正診として不一致について検討した。ホホリープに つい, 注腸の偽陰性は11病变， $32.3 \%$ ，偽陽性は 3 病変, $8.8 \%$ であった。CF の偽陰性は 8 病変, $23.5 \%$ であった（表 6)．注腸のボリープ偽陰性及び䴂陽性病 変は全て S 状結腸，直腸にあった。この原因について
㤗 4 前処昷，注渴造影所見の評価

\begin{tabular}{|c|c|c|c|}
\hline & & 前期 $(n=49)$ & 媛期 $(n=62)$ \\
\hline \multicolumn{4}{|l|}{ 注晹 } \\
\hline & 前処賁不良 & 3 & 5 \\
\hline & $\mathrm{Ba}$ 移動不度 & 2 & - \\
\hline & 粘膜描出不良 & 7 & 12 \\
\hline & 造影不良 & 6 & 9 \\
\hline \multicolumn{4}{|l|}{$\mathrm{CF}$} \\
\hline & 前処置不良 & 4 & 7 \\
\hline & 浣䦪必要 & 6 & 0 \\
\hline
\end{tabular}

前期: S 58. 1

啳期：S58. $6 \sim \mathrm{S} 59.5$

表 5 CF・注渴同日併用例

\begin{tabular}{|c|c|c|}
\hline 垁患 & 病変/症例数 & 频度 $(\%)$ \\
\hline 癌 & 6 & 5.4 \\
\hline ボリープ & $34 / 25$ & 22.5 \\
\hline 大腸 资 & 6 & 5.4 \\
\hline 㵒湟性大晹资 & 1 & 0.9 \\
\hline 秘 & 5 & 4.5 \\
\hline
\end{tabular}

表 $6 \mathrm{CF}$ と注䳟 X 線所見の不一致

\begin{tabular}{|c|c|c|c|}
\hline & \multirow{2}{*}{$\underset{\text { 漹陰性 }}{\mathrm{CF}}$} & \multicolumn{2}{|c|}{ 注腸 X線 } \\
\hline & & 偽陰性 & 偽陽性 \\
\hline 癌 & 0 & 0 & 0 \\
\hline ポリーブ & 8 & 11 & 3 \\
\hline 大踢资 & 0 & 6 & 0 \\
\hline 憩 室 & 4 & 0 & 0 \\
\hline
\end{tabular}

衰 7 CF · 注腈 X 緗不一致の原因

\begin{tabular}{|c|c|c|c|}
\hline $\mathrm{CF}$ & 偽陰性 & 観察範围外 & 8 \\
\hline \multirow[t]{4}{*}{ 注腸 } & 偽陰性 & $<6 \mathrm{~mm}$ 小病变 & 4 \\
\hline & & 前処置 - 造影不良 & 7 \\
\hline & & 軽度の炎症 & 6 \\
\hline & 偽陽性 & 前処置造影不良 & 3 \\
\hline
\end{tabular}

(例)

検討すると, $6 \mathrm{~mm}$ 以下の小病変のためが 4 病変, 前処 置，注腸造影不良のためが10病変であった（表 7)。

6. CF 単独と CF，注腸 X 線同日の診断病変

$\mathrm{CF}$ 単独例は病変を発見, ハイオプシー, ポリペクト ミ一等施行し，注腸 X 線検查を中止したものである。 CF 単独の診断病変は104症例中癌15例, ポリープ16 例, 23病変, 大腸炎 14 例, 潰場性大腸炎 3 例で, CF. 注 
表 8 診断病变

\begin{tabular}{|c|c|c|c|c|}
\hline & $\begin{array}{l}C F \text { 単独 } \\
(n=104)\end{array}$ & 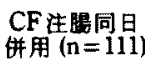 & \multicolumn{2}{|c|}{ Total } \\
\hline & 病変/症例数 & 病変/应例数 & 病窔/症例数 & 频度 $(\%)$ \\
\hline 癌 & 15 & 6 & $21 / 21$ & 10.2 \\
\hline ボーブ & $23 / 16$ & $34 / 25$ & $57 / 41$ & 20.0 \\
\hline 大 腸 炎 & 14 & 6 & 20 & 9.7 \\
\hline 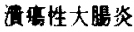 & 3 & 1 & 4 & 1.9 \\
\hline 䝷 & - & 5 & 5 & 2.4 \\
\hline
\end{tabular}

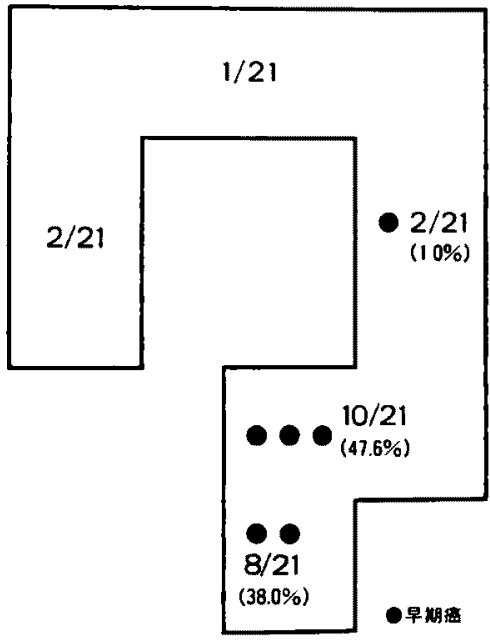

図 1 满占居部位

腸 X 同日検查例を合わせると癌21例，ポリーブ41例， 57病変が診断され，隆起性病变の診断は約30\%であっ た（表 8 ）。これら癌の占拠部位は直腸 8 例， $38.0 \%$, $\mathrm{S}$ 状結腸 10 例， $47.6 \%$ で行結腸を含めた左側結腸は 約 $85 \%$ であった。早期癌は 6 例で $\mathrm{S}$ 状結腸，直腸に 5 例発見された(图 1)。ボリープの占䇋部位は直腸12病 变, $21.0 \%, \mathrm{~S}$ 状結腸 31 病变, $54.4 \%$,下行結晹 5 例約 1\%であった．S 状結腸，直腸に75\%が占拠していた (図 2 ).

\section{7. 瘏疾患との併存病变}

前期（昭和59年 1 月〜 5 月）のみの検討であるが， 69例中痔疾患患者は35例であり，その併存病变は癌 1 例，ボリープ 7 例で約 $23 \%$ に隆起性病变を合併してい た（㤗9）.

\section{考察}

大腸癌早期発見の手段”として, 問診, 直腸診, 便潜 血反応、ロマノスコーブ3)，S 状結腸ファイバー，注腸 $\mathrm{X}$ 線桧査 ${ }^{4) 5)}$ ，Total Colonoscopy (TCF) などの，集 団検診、スクリーニング険查があり，それぞれ工夫さ

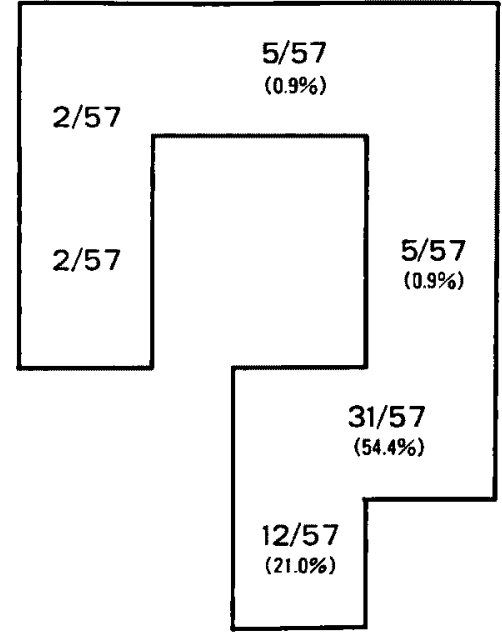

图2 ポリープ占居部位

表 9 痔疾患併存病变

\begin{tabular}{c|c|c}
\hline & 症例数 & 頪度 $(\%)(\mathrm{n}=35)^{*}$ \\
\hline 症 & 1 & 2.8 \\
ボリーブ & 7 & 20 \\
大腸 炎 & 4 & 8.6 \\
\hline \multicolumn{2}{|l}{} & $31.4(\%)$ \\
\hline ・前期の2検討
\end{tabular}

れているがいまた確立されていない． 又，下血，血便， 便通異常. 腹痛等の下部消化管有愁訴者に対するスク リーニンク，精密検查も各施設それぞれに工夫施行さ れているのが現状である7．新鼬県小千谷総合病院で は昭和52年より昭る57年迄に，下部消化管有愁訴者に 対しロマノスコープ, 注腸 X 線同日併用検查を施行し てきた。この間の結腸直腸癌は129例, 137病変であり， $\mathrm{S}$ 状結腸直腸癌は95病変, $69 \%$ で, 左側結腸は99病変, 73\%であった，他施設の報告も同様 ${ }^{(3) 9)}$ で，S 状結晹直 腸は病変の好発部位であり，全大晹癌の約 $60 \%$ は口

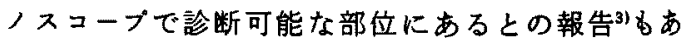
る.しかし，このS 状結晹直腸は注腸 X 線検㚗で盲点 の多いところといわれ(5)10), 又, ロマノスューブで全て を網羅することは出来ない，故に，昭和58年 1 月より ロマノスコープを，中間長フフイハースコーブに变え $て \mathrm{CF}$ ，注腸 $\mathrm{X}$ 線同日併用検査を施行し $\mathrm{S}$ 状結腸直腸 を中心とした左側結腸の double checkを施行した。同

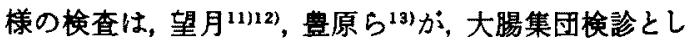
て, 斉藤ら ${ }^{14)}$ が有愁訴例に施行している. 又, 北野 ${ }^{15)}$, 野垣 (16) $^{(5 ;}$ ，大腸垁患患者に TCF，注腸 X 線検査同日 
併用し良好な成责を報告している。

しかし，大腸内視鏡検查啳の注腸 X 線検查は，直腸 スバスム, air lock, 粘液分泌六進等により良好な注腸 二重造影には好ましくなく，又，大腸穿孔が起こり易 いとされだ7. CF．注腸 X 線検查同日併用の報告者 は, 何れも注腸二重造影の所見でパリウムの粘膜の付 着状態が不良であったとしているが，診断に支障を来

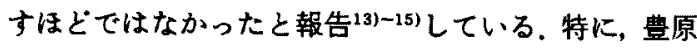
$5^{13}$ ) は，CF。注腸 X 線検查同日併用例を後日，注腸 X 線の再検查を施行した結果, 同日施行 X 線検查と, 後 日のX線再検查との間には診断能に於て差がなかっ たと報告している.

大渴癌早期発見における専門施設511018189)での注腸 $\mathrm{X}$ 線険查の診断塞態は,ポリーブについて為陰性 7.4 15\%で，偽陽性は19.6〜31.9\%で，6mm 以下の 病変になると為陰性22.5３0\%の高率となっている. 斉藤ら ${ }^{20)} 5 \mathrm{~mm}$ 前後のポリープの検討では偽陰性，偽 陽性率はすっと高率であり，左側結渴に比へ右側結腸 でより高率となっている。豊原ら ${ }^{13}$ は X 線内視鏡同日 併用検查を施行し，注腸 X 線検查で6 mm 以下のは 30〜 $42 \%$ と高率で見落とされている，しかし，注腸 X 線検査を再施行しても，ポリーブの描出能は大きさ， 占拠部位などです同日注腸 X 線検查と同等で見落と され，CF 先行による悪影䈉については否定的である。 我々の同日併用注腸 X 線検查の見落とし率は $32.3 \%$ であり，注腸二重造影不良のため11個のポリーブが偽 陰性，偽陽性となった。

一方，CFであ6 $6 \mathrm{~mm}$ 以下のポリープの見落とし率は

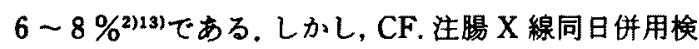
查により double checkができ，より多くの小ボリーブ の拾い上げが可能になると考えられる。

岡本ら²11はTCFにより大腸䵊小ポリープの分布を 検討し， $5 \mathrm{~mm}$ 以下では左側結腸で59\%であり，横行結 腸 $18 \%$ ，右側結腸 $23 \%$ で横行結腸と右側結腸で $41 \%$ と なり, 全大腸に均等に分布していた.しかし6 $\mathrm{mm}$ 以上 のポリープでは左側結腸71\%，右側結腸 $9 \%$ となり右 㑡が堿少し，左側が優位に分布していると報告した。 Shinya ${ }^{22)}$ は6,942個のボリーブ中75\%が左側結腸にあ $\eta, \mathrm{m}$ 癌の $85 \%, \mathrm{sm}$ 癌の $82 \%$ が左側結腸にあったとし ている、長趈 ${ }^{23)}$, 野垣ら ${ }^{16)}$ 腺看は全大腸に均等に分布 していると報告しているが，早期癌は左側結腸に 84〜89\%あったとしている. 又, 野垣ら ${ }^{161}$ は, 進行癌に

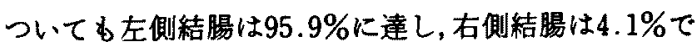

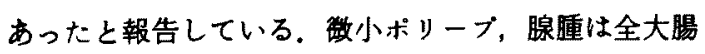

に均等に分布しているが，早期泚では左側結腸が優位 になり,進行癌になるとさらに顕著となるよらである. この原因として, adenoma-cancer sequence に基つけ ば carcinogen, initiator は全大腸に均等に分布する が, promotorが左側結腸に優位であると考えられ る24. 特に promotor としての胆汁酸25)が注目されて いるがこの点に関しては今後の研究問題である.

野垣ら 26)は, 進行癌が左側結腸に多く，その愁訴は肛 門出血, 疼痛, 粘血便, 腹痛, 下浰, 排便異常等であ り，肛門疾患と紛らわしい愁訴で外来を訪れていると 報告した，我々の検討でも肛門疾患類似の愁訴で外来 を訪れる患者が約75\%であり，実際にその50\%が何等 かの肛門疾患を有していた。それら肛門疾患患者には， 癌 1 例，ポリーブ 7 例と $23 \%$ の隆起性病変を合併して いた.䀴門疾患類似の愁訴で訪れる進行癌があること， 肛門疾患が存在しても癌やポリープが併存しているこ とを念頭にお゙，必ず全大腸を精查すべきである。

一方, 微小ポリープ, 腺腫が全大腸に均等に分布し ているすのの, $5 \mathrm{~mm}$ 以下の大きさのポリープが癌であ る頻度は0.4\% ${ }^{21)}$ であるとされている.従ってより大き な腺腫, 早期癌, 進行癌は左侧結腸に偏在して扣り, $\mathrm{CF}$. 注腸 X 線同日併用検查による左側結腸の double check と注腸 $\mathrm{X}$ 線検査による深部大腸のスクリー二 ングは，大腸癌の早期発見の手段として十分効率がよ いと思われる。

注腸 X 線検査, CF 検査は共に被検者にとって苦痛 や負担となる前処置の問題 ${ }^{14)}$ がある. 従来の注腸 X 線 倹查後の CF 検查では前処置が 2 回上負担が多く, 時 間的損失も加わり，特に，外来患者では問題となる. この点加らも，CF. 注腸 X 線検查同日併用は被検者の 負担を軽減する，CF を先行することで, 病変の生検組 織診断,ポリペクトミー等により, 早期猃断, 早期治 療が可能となる, 又, 注腸 X 線検查で描出困難な軽度 の大腸资む診断可能であり，場合によっては，同日の 注腸 X 線検查を省略できる利点もある. 今後, TCF が Shinya ${ }^{22)}$ のごとく誰にです数分で間便にできるよう になれば，早期胃癌発見における内視鏡検查と同様， 大腸癌早期発見の手段として最む有用な検查法となり らるであろら。

\section{結語}

1. CF. 注腸 $\mathrm{X}$ 線同日併用娭査は, 前処置が 1 回で 被検者の負担が軽减される。

2. 有愁訴者に CF 検査を先行することで早期猃断, 早期治㞠が可能となる。 
3. CF 注腸 X 線同日併用㭘查により病変の好発す る左側結腸，特にS 状結腸，直腸の double check $か ゙$ 可 能であり，大渴癌の早期発見には有用な手段である。

4. 外科外来では肛門疾患と紛らわしい愁訴がある 場合，必ず大腸を精査すべきである。

5. CF を先行することで air lock，粘液分泌等によ り注腸二重造影所見が悪く，X 線診断能の低下が考え られる。

\section{文 献}

1) Saito $H$, Tsuchida $S$, Nakaji $S$ : An immunologic test for fecal occult blood by counterimmunoelectrophoresis. Higher sensitivity and higher positive reactions in colorectal cancer than single radical immunodiffusion and hemoccult test. Cancer $56: 1549-1552,1985$

2）武藤徽一郎，相沢 中，多田正大他：大腸癌早期猃 断における内視鏡の位置つけ，粉会抄録，バネル ディスカッションII, Gastroenterological Endoscopy $23: 1614-1629,1981$

3）花井洋行，金子栄藏，渡讱文利他：隆起性病変の発 見能からみた外来㨁腸鏡検查ルチーン化の意義に つい, て, Gastroenterological Endoscopy $24: 1882$ $-1891,1982$

4）丸山雅一，杉山霓義，竹腰隆男他：大腸の $\mathrm{X}$ 線䧐 断一ポリーブ, 早期癌, 小さな進行癌を中心に, 胃 之腸 8:718-732, 1973

5）松浦啓一，北川晋二：大腸の小隆起性病变の $\mathrm{X}$ 線 猃断描出能について, 日臨 $39: 2095-2102,1981$

6) Winawer SJ: Screening for colorectal cancer. An overview. Cancer 45:1093-1098, 1980

7）第24回大腸癌研究会, 大腸癌の新しい挨査法之診 断法. 東京, 1986, p-31

8）北条慶一：大腸䍄，内科 Mook, No， 14，金原出 版, 1980

9）高楿 芓, 池田孝明：大腸癌の治療成績之部位別 にみた特徵。消化器外科せミナー, 15，へるす出版， 1984

10）喥川正嗣，狩谷 淳, 白壁彦夫：大晹ボリーブに対 する X 線診断能の考察，臨放線 $25: 243-248$, 1980

11）望月福治，伊東正一郎，池田 卓他：ファイパース フーブX 線同時併用に上る大腸集団検啥，日本大 腸肛門病会誌 $34: 248,1981$

12）望月福治：Short Colonoscopy 注腸造影同日换查 の merit-demerit, Gastroenterological Endos- copy $23: 1620,1981$

13）豊原時秋, 望月福治, 伊東正一郎他：大腸癌早期発 見の立場からみた X 線一内視鏡同日併用検查の メリット，ディリット，胃と腸 $21: 243-250$, 1986

14）斉藤治, 岩越一正宗 研他：ジグイドスュ ビー注腸検查同日併用法の検討, Gastroenterological Endoscopy $24: 788-792,1982$

15）北野 宽，野垣正宏，野垣正樹他：注腸 X 線検直 同日併用 Total Colonoscopyによる大得精密 クリーニンクの有奻性, 日本大腸肛門病会誌 $37: 603-607,1984$

16）野垣茂吉，野垣正宏，野垣正樹他：左側結腸に招け る大腸早期癌診断の実態一実地医家の立場加 一，胃と腸 21：281-285，1986

17) Seaman WB, Wells $J$ : Complications of the barium enema. Gastroenterology $48: 728-737$, 1965

18）松川正明，根来 孝, 碓井芳樹他：大腸早期癌にお けるX 線診断の実態，胃と腸 21：251-257, 1986

19）丸山雅一：X 線診断一ポリーブ，㴽の存在訩断と 質的診断，臨放線 25：709-716，1980

20）斉藤幸夫, 武藤徽一郎, 大矢正俊：右側結腸に拈け る大腸早期癌の診断能の比較，胃と腸 21 ： $271-279,1986$

21）岡本平次：大腸微小ポリーブ (5mm 以下)の内梘 鏡学的, 組織学的検討一 $6 \mathrm{~mm}$ 以上のポリーブと対 比してー, Gastroenterological Endoscopy 27: $162-175,1985$

22) Shinya H : Colonoscopy : Diagnosis and treatment of colonic disease. Igaku-Shoin, New York, Tokyo, 1982

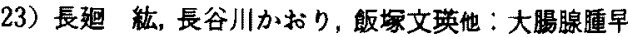
期訩断に拔ける内梘鏡の立場, total colonoscopy 例に上る検討，胃と腸 $21 ： 259-269 ， 1986$

24) Hill $M$ : Etiology of the adenoma-carcinoma sequence. In the pathogenesis of colorectal ca. ed. by B.C. Morson 153-162, W.B. Saunders, Philadelphia, 1978

25）成澤富雄：胆汁酸代謝と大腸発癌。消化器外科也 ミナー, 人るす出版, 東京, 1984

26）野垣茂吉：私的肛門科専門病院の概㳘（特に自稌 大腸腺腫と癌症例の検討並びに直腸腫韵局所切除 の適用について), 日本大腸肛門病会誌 37 ： $308-315,1984$ 


\title{
COMBINED EXAMINATION OF COLONOFIBERSCOPY AND BARIUM ENEMA STUDY FOR COLO-RECTAL DISEASE
}

\author{
Susumu OWADA, Izumi TAKEYOSHI, Shigeyuki MINAGUCHI, Seiji NAKAMURA, \\ Shigeru IWAZAKI, Yukio MIYAMOTO and Masaru IZUO \\ Second Department of Surgery, Gunma University School of Medicine \\ (Director: Prof. Masaru IZUO) \\ Tadahiro YOKOMORI, Touichirou TANIGUCHI and Hiroshi IESATO \\ Ojiya General Hospital, Niigata Prefecture
}

With a view to the early diagnosis of colo-rectal cancer, we combined colonofiberscopy (CF) followed by barium enema study on the same occasion. There were 111 cases of combined examination and 104 of $\mathrm{CF}$ examination alone. The method was as follows. Bowel preparation was done by a modification of Brown's method (using 3 packs of Boncolon diet and laxatives). Initially we examined left side of the colon or the deeper colon using a CFMB3R or CFLB3 (Olympus $\mathrm{C}_{0}$., Led) by one man method without X-ray fluoroscopy. After allowing the patient to take a short rest, an X-ray examination of a barium enema study was performed.

The conclusions were as follows:

1) This method can save time and trouble for the patient because of the single bowel preparation.

2) Giving CF first may provide an earlier diagnosis and earlier treatment for patients and may sometimes prevent the neeed for X-ray barium enema study.

3) This method was highly effective for the early diagnosis of colorectal cancer because of the double check of the left side colon, especially the rectum and the sigmoid colon, where cancer and polyps occur most frequently.

4) A disadvantage of CF preceding the barium enema study was that the barium enema study was slighlty worse than usual because of air locks and increased mucous secretion. 